\title{
The Journal of Human Hypertension: looking back over 10 years of research and thinking of the future
}

\author{
DG Beevers ${ }^{1}, \mathrm{FH}$ Messerli² and H Ueshima ${ }^{3}$ \\ ${ }^{1}$ Department of Medicine, City Hospital, Birmingham, UK; ${ }^{2}$ The Ochsner Clinic, New Orleans, USA; and \\ ${ }^{3}$ Shiga University of Medical Science, Shiga, Japan
}

Keywords: hypertension; past; future

The Journal of Human Hypertension has now completed its first 10 years so perhaps the time has come to look back at our successes, our unfulfilled ambitions and think of the future. The Journal was initially founded on the basis of an expression of irritation on the part of many clinicians on the domination of the hypertension literature by papers on molecules and laboratory animals. Whilst no one would denigrate the contribution of basic scientists to the field of hypertension, the role of clinicians and epidemiologists seemed to us to have been under-recognised. The success of the Journal over the last 10 years and the unsolicited testimonials we have received suggest that may be we have got the mix about right. We said in our original declaration that we wished to act as encouragers of medical research as well as disseminators of information. ${ }^{1}$ We are pleased, therefore, to have been able to accept many papers from the developing countries. Whilst these studies have not told us anything new at a scientific level, they have made an important contribution to the worldwide awareness of hypertension. We have not opted to lower our standards but we have been sympathetic to largely descriptive studies from countries which do not have a tradition of biomedical research.

As we enter our second decade, it is perhaps worthwhile for us to review some of the recent events in hypertension and to gauge whether we have been correct in our acceptance of papers on various topics.

\section{Epidemiology}

The most important epidemiological event of the last 10 years was the publication of the INTERSALT Project. This was the biggest ever international epidemiological study of the relationship between salt intake and blood pressure (BP) which was convened by Geoffrey Rose, Michael Marmot and Jeremiah Stamler as well as Paul Elliott. Fifty-two populations were studied simultaneously in 32 countries using strictly standardised techniques and data of superb qual ity were obtained. The INTERSALT Project orig- inated in a conference centre converted from a beautiful old farmhouse in Finland near the town of Tuohilampi. Jeremiah and Rose Stamler and Michael Marmot gave the participants of the First Advanced Seminar on Cardiovascular Epidemiology the task of devising a project to answer Sir George Pickering's objections to the salt hypothesis of hypertensi on. ${ }^{2}$ During the 2 weeks of this residential course, the participants devised a project which later became known as INTERSALT.

Whilst the main findings of the INTERSALT Project were published in the British Medical Journal in 1988, the Journal of Human Hypertension was pleased to publish the crude unadjusted data in a special issue so that scientists anywhere in the world could investigate the INTERSALT data at source. ${ }^{3}$ Parts of that particular issue of the Journal do not make particularly riveting reading as it contains 76 pages of detailed tables. It is probable, however, that we made the correct decision in deciding to accept the INTERSALT data file in one special issue. The INTERSALT Project came under criticism from the food industry whose manoeuvres do no credit to the interface between commercial considerations and scientific research. The INTERSALT Cooperative Research Group could not, however, be accused of withholding their data because they were there for all to see. The 1996 re-analysis of the INTERSALT data and the attempts on the part of the salt industry to analyse the data in their own way are of great interest. ${ }^{4,5}$

Meanwhile Paul Elliott in London and the Stamlers in Chicago are devising an even more ambitious epidemiological project to be called INTERMAP, or the International Study of Macronutrients and Blood Pressure. This study will look at nutritional factors and BP in enormous detail. INTERMAP, which is effectively an extension of the INTERSALT project will undoubtedly be one of the most important epidemiological events at the time of the millennium.

The other epidemiological papers published by the Journal have largely been on a 'one-nation' basis. On the whole they tend to confirm the marked urban/rural differences in BP and these differences 
remain hard to explain. Whilst body mass index, salt intake and in some populations al cohol intake are major environmental causes of high BP, clearly there are other environmental and nutritional factors which need to be examined. The importance of many of the urban/rural comparisons that have been published is that the differences cannot be explained by genetic factors alone, although there may be genetically rated predispositions to these environmental factors, in particular salt intake.

\section{Ethnicity}

We were delighted to devote one whole issue of the Journal to a Meeting of the International Society for the Study of Hypertension in Blacks. ${ }^{6}$ The issue of hypertension in people of African origin remains a source of great interest and concern. It is important not to look at all people of an African origin as a single group but to differentiate between them. In rural Africa, in underdeveloped, low salt-consuming societies, hypertension is rare. By sharp contrast, in the USA the preval ence of hypertension in the black population is about twice that seen amongst whites. In the UK there appears to be an intermediate picture where the average BP of black people in London and Birmingham does not appear to be substantially different from white subjects. However, the fact remains that the detection and management of hypertension in black people is of a very low standard although the reasons for this are not entirely certain. In the UK, where there are substantial AfroCaribbean and Indo-Asian minority groups, sharp differences have emerged. In the Indo-Asian population, which contains a significant number of people who cannot speak English, the outlook for malignant phase hypertension is not bad whereas the Caribbean origin patients with the same diagnosis have a very poor prognosis. ${ }^{7}$ The difference between the ethnic groups, however, did not appear to be related to ethnicity itself. Black patients with their poor prognosis often present for clinical care with higher BPs and more renal failure at the outset. Careful statistical analysis shows that, taking into account all confounding variables, there appears to be no true ethnic difference in the clinical course of this particular form of hypertension. ${ }^{8}$ The black subjects have higher BPs and present later with more end-organ damage. The implications of this finding need to be translated into further research.

\section{BP measurement}

The topic of BP measurement is of great interest to all three of the Editors of this Journal. We have, therefore, been very pleased to publish a whole series of articles on the development of non-invasive BP machines including 24-h ambulatory BP systems. ${ }^{9}$ It seems to us that the problems of sphygmomanometry have not been solved even during 1996 when we celebrated the centenary of the invention of the first manometer by Scipione Riva-Rocci in Turin in 1896. ${ }^{10,11}$ A great many factors influence the BP of an individual patient at one particular moment in time, and these are related to technical considerations like cuff size and speed of deflation of mercury column as well as patient related factors and the patient/doctor interaction. We await with trepidation the possible abolition of mercury manometers from countries in the European Union, and we greet with horror the arrival of kilo-pascals as the unit of measuring BP al though this would be the logical development if mercury manometers were to be abolished. ${ }^{12}$ We hope that the non-European nations will oppose the widespread adoption of these 'progressive' changes which will be hard to implement anyway particularly in developing countries.

\section{Awareness of BP}

A great many studies were published in the late 1990s which confirmed the depressing state of underdiagnosis and undertreatment of hypertension, even in advanced prosperous countries. The increasing awareness of the importance of hypertension amongst primary heal th care workers does not as yet seem to have any major payoff in terms of improved detection and management. A recent study from the USA still shows a depressing level of suboptimal care in the management of hypertension, although one has to say that the criteria for optimal care are now stricter than they used to be. ${ }^{13}$

\section{Pharmacotherapy}

The most important pharmacological event over the last decade has been the introduction of the angiotensin receptor antagonist, Iosartan. This could be regarded as a 'designer drug' in the sense that Peter Timmermans specifically set out to synthesise a non-peptide angi otensin receptor antagonist. ${ }^{14} \mathrm{We}$ are pleased that many of the fundamental clinical papers on losartan were published in the Journal of Human Hypertension. ${ }^{15}$ It is quite apparent that the angiotension receptor antagonists do represent a major breakthrough, and this is witnessed by the decision of a great many pharmaceutical companies to develop their own compounds in the same group. We look forward with interest to see whether there are any differences between the various angi otensin receptor antagonists and whether these agents will have the same or even better beneficial effects as the angiotensin-converting enzyme (ACE) inhibitors. Furthermore, the use of these agents will undoubtedly teach us a great deal about the role of the reninangi otensin system in hypertension, renal impairment and congestive cardiac failure.

The first meta-analyses comparing the use of ACE inhibitors against other drugs in the regression of left ventricular hypertrophy was published in the Journal of Human Hypertension by John Cruickshank and his findings were subsequently confirmed by other authors. ${ }^{16}$

The advent of the long acting alpha receptor blockers, doxazosin and terazosin has perhaps had a less impressive impact on medical care. ${ }^{17,18}$ However, these drugs are very attractive as they appear to have beneficial effects on serum cholesterol levels and there are no contraindications. Furthermore, it 
is likely that they do have modestly beneficial effects on sexual function in men. They are also helpful in hypertensive men who are symptomatic from prostatic hyperplasia but they can cause stress incontinence in women. The alpha-blockers can be regarded as a useful addition to our therapeutic armamentarium but no new ground has been broken.

On the horizon we have the development of the imidazoline receptor agonists. The first, rilmenidine, is available in some countries and moxonidine has also recently been launched. A review article of moxonidine and related compounds will be published shortly in the Journal of Human Hypertension. In theory, these drugs, which have a high affinity for the central imidazoline receptors but have few central al pha agonist effects, may reduce BP without the side effects which were encountered with methyldopa and clonidine.

The activity of a synthetic nervous system has emerged as a powerful risk factor for a variety of cardiovascular disorders such as atherosclerosis, left ventricular hypertrophy, glucose intolerance, arrhythmias and congestive heart failure. A ntihypertensive therapy that elicits sympathetic stimulation may be less beneficial for a given decrease in arterial pressure than therapy that reduces the activity of the sympathetic nervous system. Conceivably the bad press of the calcium channel bl ockers may be related to the inappropriate use of short acting agents in high dose with the resulting sympathetic stimulation. There is good evidence that such sympathetic stimulation is less pronounced or lacking with the newer, better tolerated, long acting calcium channel blockers.

During 1995 there was a considerable stir amongst hypertensionologists following the publication by Psaty and colleagues of a series of papers suggesting that calcium channel blockers may cause cardiac death, a variety of cancers and gastro-intestinal haemorrhage. ${ }^{19}$ The Journal of Human Hypertension published a useful review of these papers and came to the general conclusion that the findings of these workers must be treated with considerable caution as they are not based on the gold standard of randomised controlled trials. ${ }^{20}$ The debate still rages and in the meantime there is general agreement that short-acting nifedipine should not be used in high dose. We were not, however, under the impression that many clinicians had been doing this anyway.

Whilst this Journal is primarily concerned with clinical issues, we have attempted to accept a reasonable number of papers on clinical aspects of basic science. Thus we are pleased to have been able to contribute to the world literature on the topic of the powerful vasoconstrictor, endothelin, and we have also taken an interest in the field of the isolation of the ACE gene and its impact on renal syndromes. It seems to us that a high priority for further research should be the identification of the gene which controls the sensitivity to dietary salt intake. We have also published special issues devoted to the topics of hypertension and the kidney, ${ }^{21}$ diabetes $^{22}$ and BP in children, ${ }^{23}$ as well as several issues on hypertension in the community.

\section{The history of hypertension}

It is probable that the best research may be conducted by those who are aware of the past whilst thinking of the future. The Journal of Human Hypertension has, for that reason, been happy to commission a series of articles on the history of hypertension and BP measurement, as well as biographical articles about some of the important contributors to the fiel d. Stephen Hal es, Frederick Henry Horatio A kbar Mahomed and Theodore Janeway have been covered so far, and a further article on Mahomed and one on Richard Bright will soon be published. ${ }^{24-26}$ Professor ET O'Brien's review of the 'History of blood pressure measurement' have been a worthwhile addition to our pages, as has been the publication of the panels on this topic which were on display at the Glasgow Meeting of the International Society of Hypertension in 1996.10,11,27

\section{The future}

The main problems for the future will be similar to the ones of the past. That is, how do we deliver validated health care to millions of people? We know that antihypertensive treatment is effective in pre venting both heart attacks and strokes and we know that many of the cardiovascular calamities that do occur could have been prevented were antihypertensive treatment administered on a systematic and efficient basis. This problem will not go away so we will continue to show particular interest in the problems of health care delivery in both developed and developing countries. The most important pharmacological events in the future will unfortunately not occur until after the year 2000, when a great many studies will be published comparing the different therapeutic subclasses of antihypertensive drugs to investigate whether any one class is any better than any other in the prevention of heart attacks, strokes or renal impairment. There is quite good evidence that the ACE inhibitors are better than the other drugs at effecting the surrogate end-points of left ventricular hypertrophy and proteinuria, but as yet there is no reliable information about the prevention of the hard end-points, heart attack and stroke.

The ALLHAT study in the USA and the ASCOT study in the UK and Scandinavia are exciting new ventures but we will have to be patient as there will be no results until well into the next millenium (Table 1). The Hypertension Optimal Treatment (HOT) Study is likely to be published sooner and will substantially influence clinical practice as it will tell us by how much we should reduce BP and whether aspirin is useful. Similarly the Syst-Eur Study will also be published fairly soon and this will tell us more about the value of treating isolated systolic hypertension in the elderly. ${ }^{28}$

\section{The Journal and its supporters}

Over the last 10 years we have had several sadnesses. The premature death of Daniel Savage and Tony Raine, both of whom were enthusiastic supporters of this Journal, has deprived the medical 
Table 1 Principal long-term outcome trials currently underway

\begin{tabular}{|c|c|c|}
\hline Acronym & Full title & Principal aims \\
\hline SYST-EUR & Systolic Europe & $\begin{array}{l}\text { Placebo controlled trial of isolated systolic hypertension } \\
\text { in the elderly }\end{array}$ \\
\hline SYST-CHINA & Systolic China & As above \\
\hline HOT & Hypertension Optimal Treatment & $\begin{array}{l}\text { Comparison of three target diastolic blood pressures and } \\
\text { the value of Aspirin }\end{array}$ \\
\hline HYVET & Hypertension in the Very Elderly Trial & Placebo controlled trial in patients aged $80 \mathrm{yrs}$ or older \\
\hline TOPS & Treatment of Post Stroke Hypertension & Mild hypertension in ambulant stroke survivors \\
\hline ALLHAT & $\begin{array}{l}\text { Antihypertensive and Lipid Lowering Heart } \\
\text { Attack Trial }\end{array}$ & New vs old hypertensive drugs and lipid lowering \\
\hline ASCOT & Anglo Scandinavian Coronary Outcome Trial & As ALLHAT \\
\hline STOP-H2 & $\begin{array}{l}\text { Swedish Trial in Old Patients with } \\
\text { Hypertension }\end{array}$ & New vs old hypertensive drugs \\
\hline LIFE & Losartan Intervention for Endpoint Reduction & Losartan vs atenolol in patients with LVH \\
\hline
\end{tabular}

In addition, many pharmaceutical companies are conducting their own long term outcome trials of some of the newer antihypertensive drugs. Clinical trials are also currently under way in patients with diabetes, heart failure and renal impairment which include both hypertensive and normotensive patients.

community of two extremely able scientists whose contribution to medical research had already been spectacular. ${ }^{29,30}$

Similarly, the deaths of Herbert Langford, Tony Amery and Geoffrey Rose has deprived us of great men whose contributions have been enormous and will continue to be of overwhelming importance. ${ }^{31-33}$ It causes us some sadness that Geoffrey Rose's paper on 'Salt sensitivity in a community in Brazil' could not finally be published in the Journal until after his death. ${ }^{34}$

We have attempted to keep our Editorial Board young and enthusiastic with regular additions and sadly some subtractions. When contemplating our successes, we have to pay tribute to the immense importance of our board and also of our referees. Over the years we have learned who are good referees and who are bad, who are tough and who are kind, and we choose our referees accordingly! Most important, however, has been the authors of the very large number of papers that we have been allowed to consider. Sadly we have had to reject a great many papers (around 50\%) and we suspect that we have turned away many deserving authors. We hope that our acceptance decisions have been correct even though some of them were taken against the advice of our referees.

The founding of the Nurses' Hypertension Association for the UK and Ireland was an event which we greeted with enthusiasm, and we are pleased to be given the opportunity to publish their conference abstracts. ${ }^{35}$ The more recent establishment of the Australian Nurses' Hypertension Association is similarly greatly wel comed ${ }^{38}$ and other countries should, in our opinion, follow suit.

Looking back we can be pleased with what we have achieved in the Journal of Human Hypertension but this must not stop us from thinking about future developments and possible new avenues of medical research. The term 'medical research' has itself become somewhat daunting and we would prefer to say that on occasions 'documented clinical enquiry' might be a more apt definition of some of papers that we have been happy to accept. Research is an integral part of medical care and should not be seen as something abstruse and so complex that it can only happen in centres which consider themselves to be excellent. It should not be restricted to the ivory towers of academic institutions. Any clinician working in the field of heal th care and any suitably trained nurse can formulate a hypothesis which can be tested in a clinical environment, as long as there is careful documentation and a few basic principles are adhered to after taking appropriate advice. No one in the future should feel inhibited from sending us simple clinical papers even though we as editors may give them a hard time occasionally.

\section{References}

1 Beevers DG, Messerli FH. Hypertension - moving toward the year 2000. J Hum Hypertens 1987; 1: 1-2.

2 Beevers DG. INTERSALT. J Hum Hypertens 1989; 3: 279.

3 Rose G, Stamler J. The INTERSALT study: background, methods and main results. J Hum Hypertens 1989; 3 : 283- 407.

4 Elliott $P$ et al. INTERSALT revisited: further analysis of 24 hour sodium excretion and hour pressure within and across populations. Br Med J 1996; 312: 12491253.

5 Godlee $\mathrm{F}$. The food industry fights for salt. $\mathrm{Br}$ Med J 1996; 312: 1239-1240.

6 Beevers DG. Hypertension in blacks - time for action. J Hum Hypertens 1990; 4: 67-68.

7 Clough CG, Beevers DG, Beevers M. The survival of malignant hypertension in blacks, whites and Asians in Britain. J Hum Hypertens 1990; 4: 94-96.

8 Lip GYH, Beevers M, Beevers DG. Complications and survival of 315 patients with malignant hypertension. J Hypertens 1995; 13: 915-924.

9 O'Brien E, Mee F, Atkins N, O'Malley K. Evaluation of the Spacel abs 90202 non-invasive ambulatory recorder according to the AAMI standard and BHS criteria. J Hum Hypertens 1981; 5: 223-226.

10 O'Brien ET, Semple PF, Brown WCB. Riva-Rocci centenary: on the occasion of the 16th Scientific Meeting of the International Society of Hypertension in 
Glasgow, 23-27 June 1996. J Hum Hypertens 1996; 10: 705-721.

11 Brown WCB, O'Brien ET, Semple PF. The sphygmomanometer of Riva-Rocci 1896-1996. J Hum Hypertens 1996; 10: 723-724.

12 O'Brien ET. Will mercury manometers soon to be obsolete? J Humn Hypertens 1995; 9: 933-934.

13 Burt VL et al. Trends in the prevalence, awareness, treatment and control of hypertension in the adult US population. Hypertension 1995; 26: 60-69.

14 Timmermans PBMWM et al. Discovery of Losartan, the first angiotensin II receptor antagonist. J Hum Hypertens 1995; 9 (Suppl 5): S3-S18.

15 Brunner HR. Antihypertensive therapy by Losartan. How effective is AT, receptor blockade. J Hum Hypertens 1995; 9: 859-860.

16 Cruickshank JM, Lewis J, Moore V, Dodd C. Reversibility of left ventricular hypertrophy by different types of antihypertensi ve therapy. J Hum Hypertens 1992; 6: 85-90.

17 Beevers DG. The new al pha-blockers: dubious past or bright future. J Hum Hypertens 1991; 5: 307-308.

18 Elliott HL. The case for al pha adrenocentor antagonists as first-line antihypertensive agents. J Hum Hypertens 1991; 5: 309-311.

19 Psaty BM et al. The risk of myocardial infarction associated with antihypertensive drug therapies. JAMA 1995; 264: 620-625.

20 Mackay JA, Sever PS. Calcium channel blockers in the dock: innocent or guilty. J Hum Hypertens 1996; 10: 277-280.

21 Special Issue, Hypertension and the kidney - The Tony Raine memorial symposium. J Hum Hypertens 1996; 10: 625-702.

22 Special Issue, Hypertension and Diabetes. J Hum Hypertens 1991; 5: 235-305.
23 Special Issue, Juvenile hypertension. Proceedings of the Third International Symposium on Juvenile Hypertension. J Hum Hypertens 1994; 8: 301- 400.

24 Lewis O. Stephen Hales and the measurement of blood pressure. J Hum Hypertens 1994; 8: 865-871.

25 Swales JD. Frederick Akbar Mahomed (1849-1884): pioneer of clinical research. J Hum Hypertens 1996; 10: 137-142.

26 O'Brien ET. Theodore Caldwell Janeway (1872-1927): The quest for precision. J Hum Hypertens 1996; 10: 501-504.

27 O'Brien ET, Fitzgerald D. The history of blood pressure measurement. J Hum Hypertens 1994; 8: 73-84.

28 Slovick DI et al. SYST-EUR multicentre trial of the treatment of isolated systolic hypertension in the elderly: first interim report. J Hum Hypertens 1993; 7: 201-203.

29 Obituary: Daniel Douglas Savage MD PhD. J Hum Hypertens 1990; 4: 213.

30 Ritz E. Tribute to Professor Tony Raine. J Hum Hypertens 1996; 10: 701-702.

31 Obituary: Herbert Gaines Langford MD. J Hum Hypertens 1994; 8: 1.

32 Obituary: Geoffrey Rose 1926-1993. J Hum Hypertens 1994; 8: 1 .

33 Obituary: Antoon Amery MD PhD 1933-1994. J Hum Hypertens 1995; 9: 211.

34 Costa E de A, Rose G, Klein CH, Achutti AC. Diastolic pressure as an index of salt density. J Hum Hypertens 1994; 8: 703-709.

35 Beevers M, Curzio J. Nurses Hypertension Association. J Hum Hypertens 1993; 7: 95-102.

36 West J, Armstrong R. Announcement. The A ustral ian Nurses Hypertension Association. J Hum Hypertens 1996; 10: 776. 